\title{
THE ROLE AND SKILLS OF THE FINANCE DIRECTOR IN CREATING AND MAINTAINING THE VALUE OF THE COMPANY
}

\author{
Zoran Jović ${ }^{1}$, Vladimir Jović ${ }^{2}$ \\ ${ }^{1}$ Faculty of Business in Valjevo, Singidunum University, Valjevo, Serbia \\ ${ }^{2}$ AFS, Belgrade, Serbia
}

\begin{abstract}
:
\section{INTRODUCTION}

There is often a dilemma whether the financial director in a company is a creator of new values or a "magician" who retains the values of the company. It could be said that they are neither of these, but also a bit of both. Expectations of their contribution to the company to a great extent depend on the size of the company they are leading financially, ranging from seeing them as a stable specialist to a kind of financial alchemists. Their role is crucial in securing and managing the liquidity of the company, financing of current operations, choice of investment variants and financing investments, as well as in the process of capital management of a company. The knowledge of the market is expected, sufficient technological and legal expertise to know the business of important stakeholders - customers and suppliers, as well as identifying promising directions for the development of the company and possession of good organizational skills.
\end{abstract}

In situations where the company needs additional funds, either for maintenance of liquidity, investments in current or fixed assets, it is not irelevant to the way how the company purchased them. A similar situation occurs when a company has surplus funds, it does matter where and under what conditions they will be placed. The choice between different options of credit borrowing, issuing bonds or shares, on the one hand and investments of surplus cash in fixed-term bank deposits and short-term and long-term securities in the financial markets, it lies to the finance director of the company. The success of its decisions influencing the financial performance of the company, and although finance theory can not create a new value, they very much affect the level of the profit of the company, and that is the money supply that maintains and increases the value of the company, the mass of which is as criterion values can buy new fixed assets and working capital necessary to be in the circular movement up the value of the company. Hence, the role of financial director with his professional skills can be considered crucial for the preservation and creation of the company's value.

\section{Key words:}

$\mathrm{CFO}$, the value of the company, professional skills.

\section{FINANCIAL DIRECTOR IN THE COMPANY}

In modern enterprises, financial function is usually consolidated in the financial sector, which includes bookkeeping, planning and analysis or controlling and managing funds or treasury. According to generally accepted Anglo-American terminology, the head of financial sector is CFO (chief financial officer) below whom in the hierarchy are the head financial manager - treasurer and general manager of the bookkeeping departments- controller. Although within the financial sector of companies there are accounting and financial functions, it should be noted that their role is more technical than substantive in nature. You must make a clear distinction between these two functions, as the financial functions conduct financial operations, and the accounting function is only an expression of the value of financial operations. Hence, the financial function due to its nature has the role of an active character, as it is manifested in the numerous and complex transactions and operations, and accounting functions is by its nature of a passive character as it comes to a professional recording of all business transactions.

Often the question is what is expected from the financial director of the company and what is their role in the operations of the company? The answer to this question depends largely on the size of the observed company. One study [1] shows that the role of the financial manager varies depending on the size of the company. According to it, the general managers of companies expect the following roles of Chief Financial Officer in:

- Multinational companies - a reliable, stable specialist,

- Large companies - the role of watchdog,

- Medium companies - the role of a wizard,

- Small companies - the role of an alchemist.

Obviously, the smaller the company is, of financial directors it is expected a lot more, so expectations often exceed the threshold of reality, expecting of the financial director the surreal wonders. Chief Financial Officer is responsible for organizing the financial functions of the company. Depending on the type, scope and frequency of jobs in companies, financial functions can be organized on the principles of centralization, decentralization, or the combined organization. Centralized financial function implies that all primary and secondary tasks of financial functions are performed by one service, which provides a unique approach to financial partners, primarily banks. This method of organization allows faster and more efficient recruitment and investment of funds. It also implies a lower cost of operation of the premises, equipment, information technology and better utilization of financial personnel. It enables a higher degree of division of labor and specialization within the financial sector. Easier financial control functions and movements of funds. Achieve stronger position in its relations with other business areas of the company. Decentralized financial function carries efficiency in solving problems on the spot, multiplies and stimulate the financial initiative, efficiency and accountability of personnel and simplifies and speeds up the execution of certain financial transactions. On the other hand, it may bring the appearance of unrealistic competition between the executor of the financial tasks and can create unnecessary costs due to multiplication of the required number of financial employees and technical equipment. Combined mode function enables financial organizations to take advantage and avoid the disadvantages of the two previous forms of organization. This form of organization of the financial function is usually present in complex holding companies and organizations. Usually the financial function and relationships with banks and other financial institutions as well as foreign exchange transactions, is retained at the central level, while other financial functions are decentralized. Financial Director in the comany should develop an appropriate job classification. It depends largely on the size of 
the company. In larger companies the financial sector is divided into control and accounting part. The control part of the financial functions covered by the CFO includes many important managerial and professional positions. These are the following positions in the financial sector company: financial analyst, credit analyst, money manager, manager of capital expenditures, manager of project finance, foreign exchange managers, pension funds and so on. Accounting part of the financial function combines the jobs that are responsible for accounting operations, performance of the obligations in respect of taxes, making periodic and final accounts and cooperation with audit companies.

\section{ROLE OF THE CFO IN THE COMPANY}

The role of the Chief Financial Officer of the company is that their decisions and planning, organizing, leading and controlling the work process and workers, ensure the realization of the main tasks of financial sector in companies such as financing current operations, preserving the liquidity of the company, analysis of investment projects, capital management and financing company investment. Funding of current operations of the company is a daily task and one of the most comprehensive tasks of financial management. The aim is to achieve a more rational use of working capital in the support of current production and trade. These include a range of tasks related to the projection of financial plans and programs, and are particularly important, and the financial performance of companies are significant, actions that provide maintenance and an increase in net working capital fund of the company. The competence of financial directors also includes the participation in policy sales with deferred payment, especially in credit terms in accordance with the financial-credit opportunities of the company. A special place within the tasks of financing current operations of the company, for the financial director are activities and decisions within selecting different forms of financing working capital. Reliance on possible alternatives such as bank loans, sales of receivables - factoring, the policy of using autonomous sources of funding such as prolonging obligations to suppliers, employees and the state, are among the most sensitive and sophisticated decisions that lie on the financial director. Preserving the liquidity of the company is an imperative task of the financial manager. The liquidity of the company is a barometer of financial situation of the company. It means that the company must be able to always provide service according to its contractual obligations to all stakeholders: suppliers, creditors, employees and the state, while maintaining the necessary funding structure and preserving good credit standing. Design, maintenance and operational control of the liquidity of the company is a task that creates the most pressure on financial directors, mainly in small and medium-sized firms, and especially in times of crisis, times of recession and stagnation of economic activity. According to the APR [5], in 2013, 140,358 enterprises and entrepreneurs in Serbia, at least one day could not operate due to blocked accounts, and the accounts of 99,986 companies and entrepreneurs were blocked for over 180 days and 20,577 companies and entrepreneurs were blocked for less than a month continuously. All of the important indicators of business firms such as profit, turnover, market share, brand image of the company, are relevant indicators of its successful or unsuccessful business, but if the company is not liquid, or if in your account in the bank there is not enough money to pay debts due to suppliers, creditors, employees and the state, the business is going in a bad direction which, if not taken effective measures to improve the liquidity of the company, can lead to business failure. In a situation of strong competition, only dynamic company that is constantly evolving can survive in the market. Such companies are in need of new investment in maintenance and capacity expansion, modernization in equipment and technology, conquering and new product launches. Therefore, the analysis of investment projects appears to be an essential task of the financial function of the company and a financial liability of directors. It is important to make the right choice between more investment variants and to be among the options that increase the shareholder value of the company, or carry a higher rate of return than the cost of capital, choose the one that carries the biggest spread between rates of return and cost of capital. If you do not perform the proper analysis and evaluation of investment projects, it may happen that the selected investment projects increases the production volume and realized income, but still has a negative impact on long-term profitability of the company and the amount of the equity capital of the company. Also one of the tasks in realization of which is participating CFO's is the choice of favorable options in the process of modernization and capacity expansion, which can be carried out by construction of new facilities or the acquisition of existing facilities of other companies. Significant work of Financial Directors are capital management of the company. It occupies a central place in the financial management of the company because it is based on the strategic objective of increasing shareholder value of the company. Attention ofthe Finance Director shall be directed to the financial structure of the company, particularly in the ratio of its own and borrowed, or action and loan capital, which has implications on the average cost of capital of the company. Business capital management of the company includes the dividend policy that involves the distribution of realized profit on the part of the payment of dividends and forming part of the retention of capital. Also, the job of Financial Directors includes the very sophisticated work on the composition of the financial structure of the firm in the company of refinancing existing credit commitments or withdrawing part of the share capital of the company. Financing of investment is an important task of financial sector of companies led by CFO. By providing an additional source of investment financing, the increase in fixed assets and net working capital is covered. Before the CFO stand not only providing a sufficient quantity of required financial resources, but also selection of the best prices of these commodities. Cooperation with financial institutions in the capital markets that offer a wide range of financial instruments, givesfinancial directors the ability to choose one of the options that are most suitable for their business in terms of financial structure and development opportunities of their company. There is a difference between the way of additional, investment financing of small and large companies, and in this context, financial managers can look for different solutions. For larger companies, the forms of funding are usually found in the capital market in the form of debt issues and actions, while for smaller companies usually the soutions are found in obtaining bank loans, financial arrangements or operational leasing, factoring and forfeiting. It can be said that the global task of financial directors in companies is choosing the best financing options that affect theincrease of profitability of the company. In addition to taking account of the price of any capital in a company which can be explicitly formulated as the interest rate is received on bank loans and securities issued or implicit price of the share capital, of great importance is that all the expenses of the company are kept under control, in order to increase the sales volume accompanied by adequate increase profits. To increase the profitability of the company CFO should affect the turnover of all components of the current and fixed assets, on one hand, as well as the provision of the best mix of price and payment terms of funding.

\section{SKILLS OF THE CFO}

Skills in financial management should give the CFO the ability to understand the goals and needs of others and cooperation leads to the desired results, to provide effective reports and deliver them on time, to prepare plans and budgets, to constantly think and work on process improvement. One of the overriding obligations is to turn the abundance of data and complex information into simple actions and tasks that will increase the efficiency and competitiveness of the company, which will constantly optimize processes and costs, and the risks should be quantified and reduced to the minimum level. According to one study [3] from the CFO is now expected: 
- Very good knowledge of the company market, sale and distribution of goods and services of company, the ability to predict market trends, good knowledge of internet and banking operations,

- Having a basic knowledge of the technologies had and applied by companies, familiarity with the historical indicators that can predict the movement of prices and costs of these technologies,

- Sufficient level of knowledge of rules that cover the business of the company, monitoring trends and understanding the implications of certain regulatory solutions to business firms,

- Supervision of the operations of major suppliers and customers of the company, working in their development projects, both in terms of performance and sustainability of their operations,

- Timely recognition of the possibilities of generating new sources of revenue from goods and services that rely on the already existing that company provides, or entirely new products and services which would introduce improved operating results of the company,

- The ability to set the internal organization of the financial functions of the company so as to successfully perform operational tasks are delegated to lower levels of functioning and to define financial goals and policies of the company so that it can easily track their application and implementation.

It could be argued that the financial director of the company today needs to have a number of characteristics and skills and to be the first and best financial professional, and at the same time possesses a strong commercial sensibilities, to deeply understand the core business of the company, to establish a good relationship with the people and have good communication skills, to possess a strategic mindset and is able to manage and resolve conflicts rather than create problems, to have international experience and speak at least one foreign language, have experience in a variety of businesses and industries and have experience in managing large projects that require analyst skills, to be able to work under pressure and manage stress, be in good health, to have operational experience, to adapt to change and passionately approach to the work done. Today we are witnessing the changing role of finance director who, in the modern business environment, has become a key member of business teams of equal importance as the President of the Management Board and General Manager of the company. He or she is also an internal consultant for strategic planning, tax policy, financial reporting, accounting and control.

\section{THE MOST IMPORTANT FINANCIAL DECISIONS MADE BY THE CFO}

The most important financial decisions for the creation and preservation of the values of the company that CFO makes refer to the choice of crrent funding options and investment business of the company, the choice of options in investing excess liquidity and participation in the decision-making process about the method of allocation of realized profit on dividends and capital retention by providing valid information to equity holders on the consequences of different variants of the decision on profit distribution, as well as preserving and increasing the value of the company.

\section{CONCLUSION}

The key position of Chief Financial Officer of the company is reflected in the implementation of the company's business policy by which the consent of the Finance Director is required for all the elements of the strategic plan of the company, for all the changes in procurement policies, sales and compensation. Their role isunavoidable in setting clear procurement procedures, standardization of purchase and sales contracts, ensuring strict adherence to the approved detailed budget of the company, ensuring that decisions about large investments in the expansion of company activities can not be taken without developing detailed business plans, analysis of costs and expected effects and monitoring the implementation of these activities. The important role of the financial manager is that they are responsible for the accounting function of the company which is organized and set up in a way that allows the management bodies of the company effective methods of monitoring the operations of the company in each business segment. For complex companies with several organizational units, they are responsible for providing a high level of compliance and procedures and ensuring high levels of centralization of all functions that have a significant impact on costs and revenues of the company. It is particularly interesting to follow the further evolution of the role of Chief Financial Officer of the company and the skills required to possess and recognize whether the trend of growth of the importance of this function at the company will continue.

\section{REFERENCES}

[1] Barjaktarović L., Jović Z., Milojević M., Poslovne finansije, Univerzitet Singidunum, Beograd, 2013.

[2] Ćrović M., Finansijski menadžment, Naučno društvo Srbije, Beograd, 2008.

[3] Mekić M., Moderni CFO - strateg ili računovođa, Treća CFO konferencija finansijskih direktora Srbije, Aranđelovac, Srbija, 12-13/06/2014, [available on site http://www. tsomokos.rs/sr/projects/details/44/treca-cfo-konferencijafinansijskih-direktora-srbije]

[4] www.adizes.rs (date of access 12/10/2014)

[5] www.apr.gov.rs (date of access 10/10/2014)

[6] www.profitmagazin.com (date of access 11/10/2014)

\section{ULOGA I VEŠTINE FINANSIJSKOG DIREKTORA U STVARANJU I OČUVANJU VREDNOSTI FIRME}

\author{
Zoran Jović1, Vladimir Jovićc \\ ${ }^{1}$ Poslovni fakultet u Valjevu, Univerzitet Singidunum, Železnička 5, Valjevo, Srbija, zjovic@singidunum.ac.rs \\ ${ }^{2}$ AFS, Meštrovićeva 14, Beograd, Srbija aktivfs@gmail.com
}

\section{Apstrakt:}

U situacijama kada su firmi potrebna dodatna finansijska sredstva, bilo zbog održavanja likvidnosti, ulaganja u obrtnu ili u fiksnu imovinu, nije svejedno na koji način će ih firma obezbedediti. Slična je situacija i kada firma ima višak finansijskih sredstava, nije svejedno gde i pod kojim uslovima će ih plasirati. Izbor između različitih mogućnosti kreditnog zaduženja, emitovanja obveznica ili akcija, sa jedne strane i plasmana viška novca u oročene bankarske depozite ili u kratkoročne i dugoročne hartije od vrednosti na finansijskom tržištu, leži na finansijskom direktoru firme. Od uspešnosti njegovih odluka zavisi krajnji finansijski rezultat poslovanja firme, pa, iako finansije teorijski ne mogu da stvore novu vrednost, one i te kako utiču na nivo ostvarene dobiti firme, a to je novčana masa koja održava i uvećava vrednost firme, masa kojom se kao merilom vrednosti mogu kupiti i nova osnovna sredstva i neophodna obrtna sredstva koja će u procesu kružnog kretanja uvećati vrednost firme. Otuda se uloga finansijskog direktora sa njegovim profesionalnim veštinama može smatrati ključnom za očuvanje i stvaranje vrednosti firme.
}

\section{Ključne reči:}

finansijski direktor, vrednost firme, profesionalne veštine. 